\title{
CLEAVAGE OF ONE- AND TWO-CELLED RABBIT EGGS IN VITRO AFTER REMOVAL OF THE ZONA PELLUCIDA
}

\author{
R. G. EDWARDS* \\ Cellular Biochemistry Laboratory, Department of Biochemistry, University of Glasgow
}

\section{(Received 4th February 1964)}

The following experiment was performed to study cleavage in one- and twocelled rabbit eggs after removal of the zona pellucida.

Adult rabbits were killed between 18 and $30 \mathrm{hr}$ after natural mating. Under sterile conditions, the one- and two-celled eggs were flushed from the Fallopian tubes with Hanks' salt solution buffered with tris-citrate buffer. They were washed twice, then transferred into a $1 \%$ solution of Pancreatin (L. Light \& Co) or the protease Pronase (Calbiochem) (Mintz, 1962) for between 5 and $30 \mathrm{~min}$ to remove the albumen coat and the zona pellucida. Pronase was more efficient than Pancreatin especially in digesting the albumen layer, although it was seldom that either enzyme removed the zona completely. The remaining part of the zona pellucida was removed by drawing the eggs in and out of a fine Pasteur pipette until the zona split and the egg could be drawn gently out. Examples of rabbit eggs with and without membranes are shown in Pl. 1, Figs. 1 and 2 .

Eggs denuded of the zona were transferred singly into microdrops of culture medium maintained under liquid paraffiin, the paraffin having previously been equilibrated with culture medium and $5 \%$ carbon dioxide in air. Falcon plastic culture dishes (Gateway International Inc) were used throughout. The cultures were incubated at $37^{\circ} \mathrm{C}$ in a humid atmosphere of $5 \%$ carbon dioxide in air. Various media were used for culturing the eggs (see Table 2). Feeder layers of irradiated HeLa cells were used in some of the microdrops.

Sixty-eight one-celled and forty-seven two-celled eggs were cultured after removal of the zona pellucida. Thirteen of the one-celled and one of the twocelled eggs failed to cleave. The remainder cleaved once or more. Details of the cleavage intervals of thirteen one-celled and eight two-celled eggs are given in Table 1; the remaining eggs cleaved at similar rates although their progress was not recorded in such detail.

Blastomeres produced by the cleavage of the eggs separated from each other after cleavage. In some cultures the blastomeres were totally separate, and were found in different parts of the microdrop. In others, they were found together, but were only just in contact with each other (P1. 1, Fig. 3). The cells

* Present address: Physiological Laboratory, University of Cambridge. 
remained separate throughout cleavage, except in some cultures which reached the thirty-two-celled stage, and in which some cell-to-cell adhesion seemed to occur. The maximum number of cells found after 6 days of incubation was

TABLE 1

GLEAVAGE INTERVALS IN GELL CULTURES DERIVED FROM ONE- AND TWOCELLED RABBIT EGgS DENUDED OF THEIR ZONA PELLUCIDA

\begin{tabular}{c|c|c|c|c|c|c|c|c|c}
\hline \multirow{3}{*}{$\begin{array}{l}\text { No. blastomeres } \\
\text { in culture drop }\end{array}$} & \multicolumn{6}{|c}{ Embryonic stage when zona pellucida removed } \\
\cline { 2 - 7 } & \multicolumn{3}{|c|}{ One-celled } & \multicolumn{5}{|c}{ Two-celled } \\
\cline { 2 - 8 } & $20 *$ & 30 & 40 & 48 & 28 & 34 & 45 & 54 & 60 \\
\hline 1 & $13 / 13$ & $4 / 13$ & & & & & & & \\
2 & & $9 / 13$ & $6 / 9$ & & $8 / 8$ & $2 / 8$ & & & \\
8 & & & $3 / 9$ & $9 / 9$ & & $6 / 8$ & $1 / 8$ & & \\
16 & & & & & & & $7 / 8$ & $8 / 8$ & $2 / 8$ \\
& & & & & & & & & $6 / 8$ \\
\hline
\end{tabular}

Results are classified according to the proportion of cultures which possessed the stated number of blastomeres after various periods of incubation.

* Incubation time in hours after natural mating.

thirty-two to sixty-four despite the use of several culture media (Table 2). Rabbit serum was evidently beneficial to the embryos. Termination of cleavage was rapidly followed by the death of the cells.

TABLE 2

NUMBER OF GELLS FOUND IN GULTURES OF ONE- OR TWO-CELLED EGGS DENUDED OF THEIR ZONA PELLUGIDA

\begin{tabular}{|c|c|c|c|c|c|c|c|c|c|c|c|c|}
\hline \multirow{2}{*}{ Culture media* } & \multirow{2}{*}{$\begin{array}{l}\text { Stage when } \\
\text { zona pellucida } \\
\text { removed }\end{array}$} & \multirow{2}{*}{$\begin{array}{l}\text { No. } \\
\text { embryos }\end{array}$} & \multicolumn{10}{|c|}{ No. cells in culture drop } \\
\hline & & & 2 & 3 & 4 & 5 to 7 & 8 & 9 to 15 & 16 & 17 to 31 & 32 & 33 to 64 \\
\hline Waymouth's & $\begin{array}{l}\text { One-celled } \\
\text { Two-celled }\end{array}$ & $\begin{array}{l}21 \\
20\end{array}$ & 2 & 2 & 3 & $\begin{array}{l}4 \\
3\end{array}$ & $\begin{array}{l}5 \\
4\end{array}$ & $\begin{array}{l}2 \\
4\end{array}$ & $\begin{array}{l}3 \\
3\end{array}$ & 4 & 2 & \\
\hline $\begin{array}{l}\text { Waymouth's }+ \\
10 \% \text { rabbit } \\
\text { serum }\end{array}$ & One-celled & 10 & & & 1 & & 1 & & 2 & 3 & 1 & 2 \\
\hline Fischer's & $\begin{array}{l}\text { One-celled } \\
\text { Two-celled }\end{array}$ & $\begin{array}{l}19 \\
12\end{array}$ & & & 2 & 4 & $\begin{array}{l}2 \\
5\end{array}$ & $\begin{array}{l}6 \\
1\end{array}$ & $\begin{array}{l}2 \\
4\end{array}$ & 3 & 2 & \\
\hline F 10 & $\begin{array}{l}\text { One-celled } \\
\text { Two-celled }\end{array}$ & $\begin{array}{r}5 \\
14\end{array}$ & & & & $\begin{array}{l}2 \\
3\end{array}$ & 4 & 3 & $\begin{array}{l}2 \\
2\end{array}$ & 2 & & \\
\hline
\end{tabular}

* Media contained 4\% human and $6 \%$ calf serum unless otherwise stated. Details of these media are to be found in the following references: Waymouth's and Fischer's in Paul (1961), F 10 in Ham (1963).

From these results, it appears that one function of the zona pellucida is to hold the blastomeres together during early cleavage, for without the zona the blastomeres fail to adhere to each other. Damage to the cell surface by Pronase 
PLATE 1

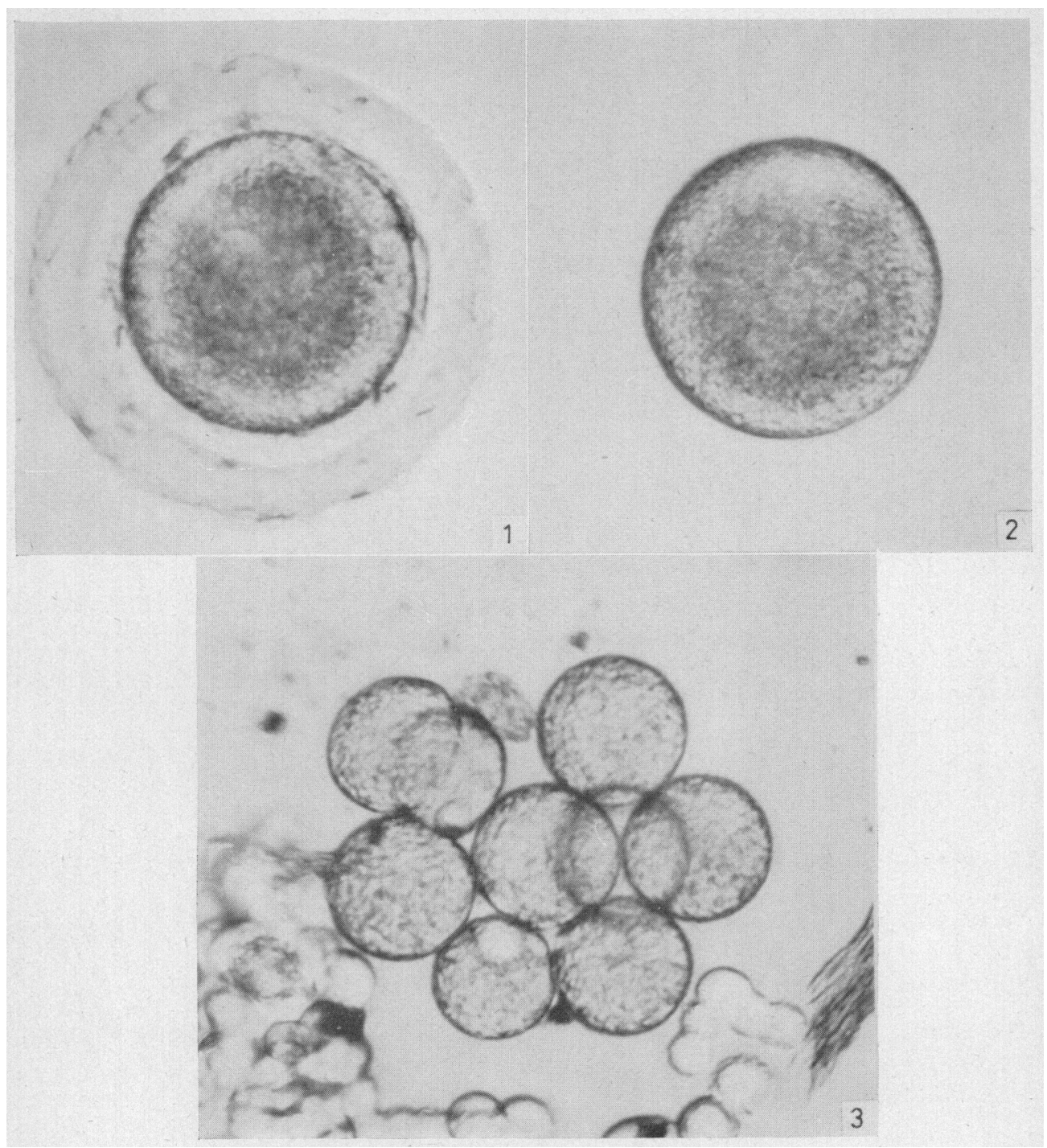

Fig. 1. One-celled rabbit embryo with intact zona pellucida and albumen layer. $\times 350$ approx.

FIG. 2. One-celled rabbit embryo after removal of the albumen layer and the zona pellucida. $\times 350$ approx.

FIG. 3. Group of nine blastomeres derived from a one-celled rabbit egg denuded of its albumen layer and zona pellucida. The cells are of uniform size and are just touching each other. The small cells are HeLa feeder cells. $\times 350$ approx.

(Facing p. 414) 
or Pancreatin during removal of the zona might have led to separation of the blastomeres, but this appears unlikely since much of the zona was intact after digestion and had to be removed mechanically. Moreover, digestion was not especially harmful since (a) intact rabbit embryos (i.e. with zona) did not cleave beyond the sixty-four-cell stage under our conditions (see also Lewis \& Gregory, 1929) and (b) the intervals between early cleavages in our cultures were only slightly greater than occurs in the rabbit embryo in vivo (e.g. Adams, 1956).

Failure of any of the cells to adhere to the plastic container contrasts with the behaviour in our cultures of older embryos denuded of the zona. Removal of the zonae from rabbit embryos between the four-cell stage and the blastocyst leads to the appearance of a cell type, probably trophoblast, which attaches very quickly to the container and grows as a monolayer; other cell types then grow over the trophoblast. Mouse embryos behave similarly (R. J. Cole, personal communication, 1963). A similar phenomenon has been reported for several cell types in Amphibians, the first indication of differentiation being the attachment of the cells to the glass culture vessel (Jones \& Elsdale, 1963). Absence of this phenomenon in cultures from one- and two-celled rabbit eggs indicates that the differentiation of the trophoblast is suppressed after removal of the zona. Perhaps the planes of cleavage are so altered in the absence of the zona pellucida that the differentiation into trophoblast and inner cell mass by the eight-cell stage (Dalcq, 1957; Tarkowski, 1959) is prevented.

I wish to thank Dr John Paul for laboratory facilities and both him and Dr R. J. Cole for many stimulating discussions. Financial support from the U.S.P.H.S. grant No. CA-05855.

\section{REFERENCES}

Adams, C. E. (1956) A study of fertilization in the rabbit: the effect of post-coital ligation of the fallopian tube or uterine horn. F. Endocrin. 13, 296.

Dalce, A. M. (1957) Introduction to general embryology. Oxford University Press.

HAM, R. G. (1963) An improved nutrient solution for diploid Chinese hamster and human cell lines. Exp. Cell Res. 29, 515.

JoNEs, K. W. \& ELSDALE, T. R. (1963) The culture of small aggregates of Amphibian embryonic cells in vitro. F. Embryol. exp. Morph. 11, 135.

LEWIS, W. H. \& GREGORY, P. M. (1929) Cinematographs of living development rabbit eggs. Science, $69,226$.

MinTz, B. (1962) Experimental study of the developing mammalian egg: removal of the zona pellucida. Science, 138, 594.

PAuL, J. (1961) Cell and tissue culture. Livingstone, Edinburgh.

TARKowski, A. K. (1959) Experimental studies on regulation in the development of isolated blastomeres of mouse eggs. Acta theriol. 3, 191. 